\title{
RUSSIA IN MODERN EURASIA: THE VISION OF A RUSSIAN GEOGRAPHER*
}

\author{
AleXANDer G. DruZhinin \\ South Federal University, Rostov-on-Don \& Baltic Federal University, Kaliningrad, Russia
}

Manuscript received: December 15, 2014

Revised version: May 30, 2016

\begin{abstract}
DruZhinIN A.G., 2016. Russia in modern Eurasia: The vision of a Russian geographer. Quaestiones Geographicae 35(4), Bogucki Wydawnictwo Naukowe, Poznań, pp. 71-79, 2 figs.

AвSTRACT: It is demonstrated that 'Eurasianism' as an interdisciplinary scientific doctrine and an object-focused area of geographical social science is at its root, generally complementary to the methodology of Russian (Soviet) socio-economic (human) geography, and corresponds to its research tradition. The geo-economic, geopolitical and geo-cultural transformation of the post-Soviet 'Eurasian space' is analysed. The geo-concept of a multipolar 'Mega-Eurasia' is proposed and justified. It is emphasised that the effective participation of Russia as one of the dominants of the Eurasian space is associated with the non-admission of an extremely undesirable, harmful scenario for Russia as well as of its possible marginalisation and limitation to the flimsy framework of the 'Russian world'. A hypothetically possible commitment to only one of the existing global 'power centres' is also considered to be a losing one.
\end{abstract}

KEY wORDS: Eurasia, Russia, geopolitics, geo-economics, Mega-Eurasia

Alexander G. Druzhinin, av. Stachky 202/1, Rostov on Don, Russia, 344090; e-mail: alexdru9@mail.ru

\section{Introduction}

The category 'Eurasia' (and at the same time many of its derivatives, including the most 'geographised' one - 'Eurasian space') is becoming ever more popular today. It is widely used in the political vocabulary, present in scientific discourse, always appears in the media (not only Russian ones). All this is symptomatic, illustrates a trend and corresponds to the geopolitical and geo-economic circumstances which are significant for Russia and the former Soviet Union as well as for the whole world.

The collapse of the Soviet Union and the subsequent destruction of the bipolar world architectonics that had existed for almost half a century was accompanied by a renewed interest in the geo-concept of 'Eurasia' on the one hand, and by the beginning of the disintegration of what was earlier meant by the term 'Eurasian space' (camouflaged afterwards as an amorphous, fundamentally transitive structure - the Commonwealth of Independent States, CIS) on the other hand. At the same time the influence (pressure) by exogenous geo-economic and geopolitical forces on the post-Soviet states kept growing, and 'Eurasia' itself increasingly came to be seen by global and regional actors as a priority area of the geostrategic 'redistribution' - a 'chessboard' on which the fight for world domination

"This study was performed under grant 15-07-00016 from the Russian Humanitarian Science Foundation (RSF). 
continues, according to Zbigniew Brzezinski (1998).

Under the influence of the rising wave of scientific journalism, the historical understanding of Eurasia in geography as a major land mass has transformed into a geo-cultural construct of 'Eurasia' as a sub-continent. The geo-economic and geo-political reality of the beginning of the $21^{\text {st }}$ century inexorably modifies (and widens) its mental boundaries. Currently, widely-rooted and actively replicating visions of the identity of the contours of 'Eurasia' and the former Soviet Union (or, more radically, exclusively of the modern Russian Federation, Dugin 1997) are coming close to and contrast more tangibly with the 'general mainland' vision of Eurasia (Bayford 2010, Sinyak, Beschinsky 2003) which is gaining in popularity. But the possibility of various interpretations of 'Eurasian space' is also declared (Leskova 2012, Druzhinin 2014a). On the back of it the views of 'Eurasia' (as of a special, but at the same time a very specific geographical taxon) are more and more blurred, variously interpreted, losing the property of a scientific category. At the same time it has become a quasi-ideological symbol and a tool of 'real politics' in many situations.

There is a visible increase in the distance between the image of the 'Eurasian space' cultivated and replicated in the scientific and mass consciousness and the real integration and disintegration processes within the Eurasian mega-continent with its inherent spatial socio-economic, demographic and ethno-cultural changes significantly complicating an adequate knowledge (and understanding) of the actual geopolitical and geo-economic situation. This difference signifies a need for a new conceptualisation of Eurasia and for the identification of modern Russia's position in it.

\section{'Eurasian' matters in the focus of Russian human geography}

Admittedly, the 'Eurasian' concept (as an interdisciplinary scientific doctrine and an object-focused area of geographical social science) is at the root of and generally complementary to the methodology of Russian (Soviet) socio-economic (human) geography (Druzhinin 2012a) and is in compliance with its research tradition.
Starting with its conceptual origins (works by N.N. Alekseev, G.V. Vernadsky, P.N. Savitsky, N.S. Trubetskoy), it is based on the consideration of the spatial determinants of Russia's development and focuses on its identification and delimitation as a special social-geographical (primarily cultural and geographical) taxon. At a later stage, in the second half of the $21^{\text {st }}$ century, fundamental contributions to the rationalisation and popularisation of Eurasian ideas were made by L.N. Gumilev, who 'implanted' the space factor (the 'place of development' of an ethnic group) into the analysis of Russian ethno-genesis. Also, he significantly corrected (expanded) visions of 'Eurasia' as a specific geographical area in respect of nature, history, ethnos and culture. S.B. Lavrov repeatedly drew attention in the late 1980s and the first half of 1990s to Eurasianism as "an important and most urgent geopolitical concept for Russia" (Lavrov 2000: 23). In the same period, as well as in subsequent years, Russian social geography attempted to form ideas about the 'Eurasian socio-economic space' (Dmitrevsky 1995) and the 'Eurasian cultural area' (Druzhinin 1996). Eurasian concepts are used actively in geopolitical and geo-economic constructions (Dergachev 2011), they are a subject of theoretical analyses (Gladky 2006), including special, focused ones (Kagansky 2007, Zamyatin 2009, Druzhinin 2013).

Nevertheless, in today's professional community of Russian human geographers the Eurasian understanding of Russian space is not universal, 'non-historical' enough (as well as 'non-geographical'). Also (with rare exceptions, e.g. Kagansky 2007) it is deprived of much needed substantial (including constructive) criticism that, in part, illustrates the absence of an apparent interest in the subject, its sort of marginality. In the multidisciplinary palette of modern Eurasian discourse, its social and geographical aspect (which in fact was initially a 'core', but did not become a subject of an extensive scientific debate and is being developed fragmentarily, episodically) is, paradoxically, barely visible in the recent years. The basic question about the cores and boundaries of the 'Eurasian space', its location in the current geopolitical, geo-economic and geo-cultural architectonics, major trends, internal structure, and other essential forms and characteristics remain open to a large extent to a social 
geographer. "The literature on Eurasianism" as correctly noted by Kagansky (2007: 544) - "is growing like a snowball, but there is almost no investigation of the country itself". And this situation is in a stark contrast with the imperative of a broad and consistent incorporation of the 'Eurasian' problems into the subject-informative fabric of Russian social geography because, in addition to the urgent opportunistic (in the positive sense of the word) aspects of socio-geographical investigation of the Eurasian territorial socio-economic systems (including modern trends in the global positioning of Russia, Eurasian integration), the methodological and instrumental potential of a focused investigation of 'Eurasia', produced and identified geo-culturally and organised by integration and disintegration vectors, is very significant for our science. The 'sensible - super-sensible' Eurasian reality is partially mental in its genesis and nature (with elements of mythology), with the simultaneous 'materialisation' of the dominant image (as well as its predestination by real economic, ethno-cultural, political and other processes). In fact, this reality complements and completes the structure of the mosaic of the territorial organisation of society traditionally studied by social geography, while reproducing itself in it and at the top of it. The proper specificity of this phenomenon objectively converts 'Eurasian problems' into a top-priority sphere for our science where its cultural and geographical component can (and must!) interact directly, closely and effectively with the other branches of human geography.

Thus, a full-scale and correct incorporation of the 'Eurasian' phenomenon into the subject matter of modern Russian human geography presumes:

- the conceptualisation of the geographical phenomenon of Eurasia (also within the framework of a geo-cultural investigation of Russia which is currently high in demand, cf. Druzhinin, Streletsky 2015) and, on this basis, the identification of the corresponding central-peripheral structures, 'cores', borders;

- social and geographical theorising of factors, manifestations and consequences of globalisation and regionalisation (as well as general spatial integration and disintegration processes);

- a multi-scale focused investigation of nodal elements ('clamps') of the 'Eurasian space', 'bands' and 'lines' of inter-civilisational interaction, cross-border areas, variously dependent regions, etc., and

- the liquidation of a rather shaky line between the geography of foreign countries and the geography of Russia, between a country study and a regional study, between an analysis of cross-border, inter-civilisational problem situations, processes and micro-scale research. At that, it is necessary to consolidate the efforts of research teams of social geographers from different regions of Russia, as well as to organise a productive interaction with scientific communities of other 'Eurasian' (and not only 'Eurasian') countries.

\section{Invariance and multi-polarity of modern Eurasia}

Countries, like people, are multi-dimensional (Treyvish 2012). This laconic, but concise formulation is applicable to an even greater extent to a much more complex, polycentric and 'fuzzy' substance like the modern 'Eurasian space', 'Eurasia'. The physical and geographical contours of Eurasia - the largest of the continents (holding up to $75 \%$ of the world population and about $60 \%$ of the planetary economic potential calculated according to the GDP) - are quite clear, stable, generally recognised. However, this vast land mass (about 53.9 million $\mathrm{km}^{2}$ ) in itself is almost indifferent to the social space-time, including Russia, the problems of its self-development, self-identification.

"Russia" - as noted back in the 1920s by Savitski (1997: 18) - "is one of the founders of the ideas of 'Eurasianism' and occupies the main space of "Eurasia'". In the 1990s a similar point of view was expounded (more consistently and categorically) by A.G. Dugin - one of the most active modern neo-Eurasianism ideologists. He proclaimed: "Russia is the heartland, 'the geographical axis of history', land. Russia is Eurasia" (Dugin 1997: 12). It should be noted that only two and a half decades ago (when the power, institutional and cultural 'field' generated by the Soviet Union still operated) this thesis seemed to be generally quite correct, require little or no additional justification, reservations, clarifications. The socio-economic reality, however, is very 


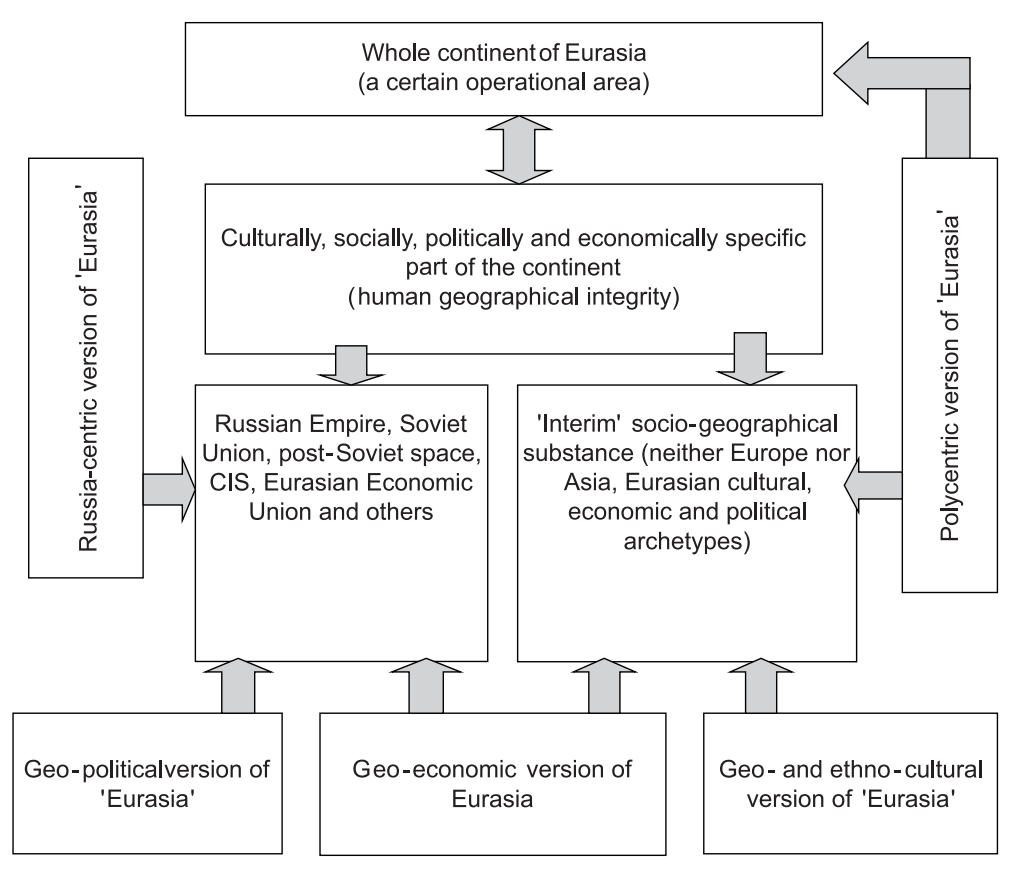

Fig. 1. Invariance of the category of 'Eurasia'.

dynamic, and a few years after the collapse of the Soviet Union the Eurasian position of Russia started to teeter significantly (in the late 1990s it was symptomatically noticed by Turovsky (1999), who stated that the real geopolitical position differed from the visions of Neo-Eurasians). In this case, in my opinion, it should be not only about geopolitics, but also geo-economics, as well as about the geo-cultural area. The geopolitical and geo-economic 'advance' of the West (the EU, NATO, the Euro-Atlantic structures as a whole) to the East (steadily continuing to this day, which is clearly confirmed by the tragic

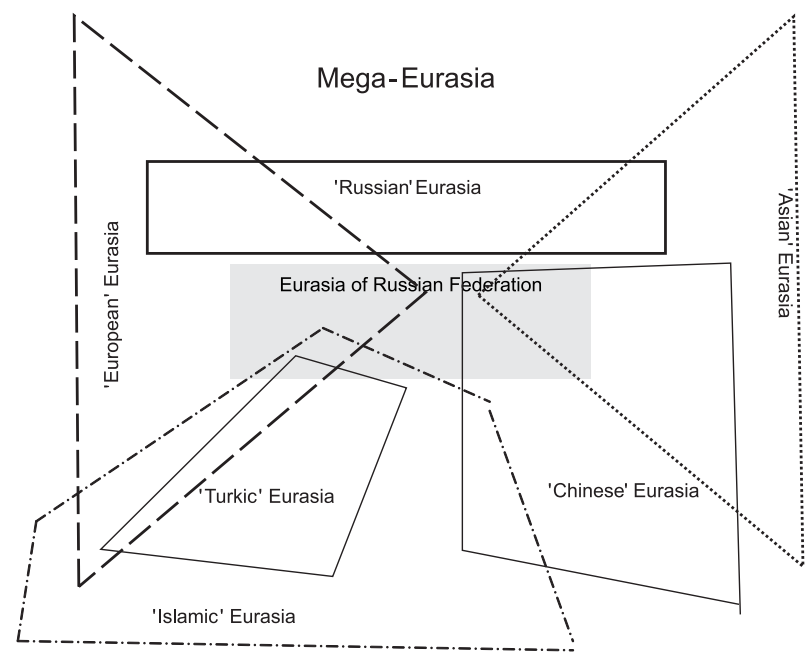

Fig. 2. Polycentric model of Mega-Eurasia: conceptual scheme. events in Ukraine), a substantial strengthening of the external economic position of China in the states of Central Asia, Mongolia, in a number of Russian regions of Siberia and the Far East, the efforts of the Republic of Turkey to gain leadership in the Turkic world, the renaissance and partial radicalisation of Islam - all this has contributed to the fact that the post-Soviet 'Eurasia' has significantly expanded (commodities and raw material flows, markets, external 'power centres' and geo-cultural dominants). At the same time, it has shrunk (with the reduction in the area where Russian is spoken, the transformation of identities, a reorientation of economic relations and others), experiencing intense erosion, acquiring an updated structure. Largely, out of alignment with political declarations, foreign relations (and, in parallel, geo-cultural, geopolitical ones) of the new independent states have acquired a multi-directional character. They are aimed not only at Russia but also at the leading economic powers of the West, China, Turkey, and at its nearest neighbours (Druzhinin 2013).

While analysing Eurasian realities, it is important to realise that in its dual socio-geographical incarnation (i.e., a land area 'saturated' by spatial systems, processes and flows, a spatial socio-economic-cultural phenomenon and, at the same time, a mental construct - see the figure above) Eurasia is now multi-dimensional, presents 
a multiplicity of non-static and actually overlapping 'Eurasian spaces'.

Its foundation supports a combination of dominant geo-economic interactions (being built up primarily by a localised energy market and related centres of concentration and redistribution channels of the natural resource rents being formed) and geo-demographic processes (and, correspondingly, migration, ethno-cultural, ethnic and religious dynamics). It also supports the co-development of the existing 'power centres' (including new ones which are acquiring a potential) and formats of inter-country Eurasian integration (the Union State of Russia and Belarus, the Eurasian Economic Union, CIS, SCO, CSTO, GUAM, CDC, and others). Partly on the foundations of the Russian Empire /Soviet Union, but in many ways out of direct alignment with them, a new, multipolar Eurasia - a kind of 'Mega-Eurasia' - has been developing during last two decades (Druzhinin 2013). It is integrated not only (and not so much) by a single state (a union of states), but also by alternative expansions, competitive to modern Russian geopolitics and geo-economics: European (EuroAtlantic), Chinese, Islamic, Turkish (Turkic), Iranian (Druzhinin 2009). Against this background, the cross-boundary Eurasian poly-dependent periphery (dependent on two and more 'power centres') - fragmented, multi-ethnic, with a mixed economy, stretching in a broad strip from the Balkans to the Far East, including the Russian Federation - is more and more noticeable as a major dominant of the post-Soviet space (as well as of the neighbouring territories) (Druzhinin 2014b). In parallel, the geo-economic interests of Russia itself increasingly go beyond the former Soviet Union.

The transition to multi-polarity results in a 'compression' of Russian Eurasia and a reconstruction of the disintegrated integrity of Eurasia (after Soviet-China 'variance' of the late 1950s and, above all, the breakup of the Soviet Union) as something to be 'above Russia', and in a number of situations also 'beyond it'. Moreover, influenced by globalisation and the post-Soviet transformation, the 'Eurasia of places' is progressively re-transforming into a 'Eurasia of flows', as well as into a 'Eurasia of places transformed by these flows'. It is already different in its spatial structure. It is a new social and geographical object, unfamiliar, practically not perceived by us. MegaEurasia (geo-cultural, geopolitical, geo-economic) proves itself to be a geo-historical heritage of the Eurasian states, to be a territory-shaped past, present and even future intersection of their geo-economic and geopolitical interests. It is constructed by the trans-frontier transport-logistic corridors, regions, markets, flows, organised by interaction networks and a hierarchy of 'archipelagos' of the largest cities-metropolises (nation-wide and regional centres), crystallised by the areas of resettlement of diasporas and localities with intensive ethno-cultural substitution.

\section{Russia's position in modern Mega- Eurasia: a geographical aspect}

It is obviously encouraging to come across statements about the 'medial position' of Russia (Chelyshev 2010) in publications of modern Russian authors, that our country is the leading power of Eurasia (Bykov 2006). It is twice as pleasant when the thesis of a 'decisive position of Russia in the Eurasian space' is confirmed by competent foreign experts (Post-Soviet states 2004). However, let us bear in mind that the position of any object is contextual, relative and not absolute (Kagansky 2007). This refers also to Russia: its position in the modern world is directly dependent on how we evaluate this world (Shuper 2003). And in this respect not only the parameters of comparison are essential (the size of the territory, its saturation with natural resources, population, economic activity, infrastructure, etc.), but also the proper spatial area of comparative studies. The geo-dynamic aspect, the direction of dominant tendencies are also worth considering. And in this connection it is obviously important that modern Russia maintains, as before, its jurisdiction over a major geographical segment of the Eurasian continent. It takes up $31.5 \%$ of all its area, which is a bit less than the consolidated figures for contiguous China, Kazakhstan, Turkey and European Union countries taken together. However, $40.4 \%$ of Eurasia is the share of the Russian Empire of the early 20th century, $41.4 \%$ that of the Soviet Union, and the follow-up dynamics displays only one of the aspects of a physical reduction of our national (cultural and territorial, civilised) presence in post-Soviet 
Eurasia, as well as more noticeably showing-up an extension of the 'peripherality' of its 'Russian segment'.

Apart from the primary energy field and the stable flow of natural-resource rent (feeding another dominant business of Russia - the field of DIC) produced by its actually all-Eurasian activity, the continent-wise geo-economic positioning of our country in the modern context is rather modest. In terms of the GDP (calculated by the purchasing-power parity) it gives up place to all the main Eurasian 'centres of forces': to the European Union by 6.2 times, China by nearly 5 times, India by 1.9 times. The continental economy of Russia is forced not to receive but rather on the contrary to pay out a 'geographical addition' permanently (New insights 2009). Brought into the severe northern latitudes, it proved to be significantly remote from the main trans-Eurasian transport and logistic flows (from China, India, countries of the Persian Gulf and farther through the Suez Canal to Europe; Inozemtsev 2012). It is a sort of geo-economic 'clamp' of the Eurasian continent.

The 'economic density' in Russia (calculated as the GDP per area) is 6.3 times lower than the continental average (overall for entire Eurasia) (USD 147 and 927, respectively); more than a 12-times distance is observed also with regard to population density (8.3 and 102 persons $/ \mathrm{km}^{2}$, respectively). Russia is homogenised (even with its Moscow megalopolis, super-normally extended for the recent one and a half decades with its concentrated demographic and financial and economic resources). It is a social and economic periphery undergoing depopulation (absolute but more substantially relative, since the Russian share both across the globe and in 'Eurasia' keeps inexorably decreasing, with rare inclusions of semi-peripheral areas; Druzhinin 2012b).

Russia certainly predominates in the post-Soviet area in geo-economic and geo-political terms, and is an essential component of the CIS, the Union State, the Eurasian Economic Union launched on 1 January 2015. Nevertheless, it is symptomatic that from the very date of the Union State Establishing Agreement coming into force, the share of the Russian Federation in the foreign trade turnover of Belarus decreased from 58\% (2000) to 45.2\% (2011). However, in 2012 and 2013 this indicator increased slightly (to 47.4 and $49 \%$, respectively). Russia lost some of its foreign trade position also in Kazakhstan: in 2007 its share in this state's foreign trade turnover amounted to $20.2 \%$, in $2010-19.7 \%$, in $2011-17.9 \%$, in 2012 $-17.4 \%$, and in $2013-17.9 \%$ (almost equal to the share of China). It is also characteristic that the share of the CIS countries in the foreign trade of the RF has been steadily declining in recent years: in $1998-22.1 \%, 2000-18.6 \%, 2005-15.2 \%, 2010$ $-13.6 \%$; only in the last two or three years those indicators grew again: to 15\% in 2011 and $16.7 \%$. In general, in line with the calculations performed by Godin (2009), during the period of 1992-2007 trade between the CIS countries shrank more than four times. During the post-Soviet period Russia has lost a considerable proportion of its influence in the Caucasus (Yazkova 2005) and Central Asia, and now is losing influence in Ukraine and Moldova. The barrier of the post-Soviet borders is extending, and, most significantly, mental, cultural ones. Even the elimination of customs borders (for example, on the Russian-Kazakh border) is not capable (as demonstrated by Gerasimenko 2012) of overcoming the trend of a deepening linguistic demarcation. Almost everywhere in the entire space of the newly independent states outlining our country 'de-Russification' takes place, although slowed down in the recent years (Druzhinin 2009). As a result, with no regard to political declarations, foreign economic (and in parallel, geo-cultural, geopolitical) connections of the new independent states are becoming multi-vector oriented not only to Russia, but also to the leading economic powers of the West, China, Turkey, and to their nearest neighbours.

'Russian' Eurasia is still produced by the exhausted inertia of the USSR, the area of a compact settlement of Russians formed in the Soviet and earlier period, according to the copyright definition of the first half of the 1990s - "the Great Russian geo-ethno-cultural system" (Druzhinin 1996). Of course, it is cemented, outlined and reproduced by the jurisdiction of the Russian Federation, its modern geo-economic potential (slightly cracked at the end of 2014 due to a sharp fall in energy prices). At the same time modern Russia, following the development path of a socio-economic periphery of the West, shows some geostrategic turn in the south-east direction (already almost tangible, but as yet poorly grounded by economic and geographical 'texture'). 
'Russian' Eurasia is still 'Eurocentric', and despite the erosion of the European identity fixed in the Russian society by sociologists (Andreev 2010), will probably remain so for at least another half-century. But the prospects of the Chinese market and an increasing geo-economic influence of China (visibly transforming into domination) in the 'Eurasian' states neighbouring on the Russian Federation (primarily Central Asia, which in an absolutely correct common judgement plays an anchor role in Eurasia; Kosov, Toropygin 2011), as well as in our regions of Siberia and the Far East, more clearly outline its dualistic prospect of acting not only as an 'Asian periphery of Europe', but also as a 'European periphery of Asia' (although for the moment it sounds unusual). According to calculations (Sinyak, Beschinsky 2003), already by 2020 the Republic of China will account for $6 \%$ of the natural gas produced in the CIS in 2050 - more than $14 \%$, and in 2100 - for almost $17 \%$.

Russia, in whose future destiny Asia will probably play the main role (according to the wise statement by F.M. Dostoevsky (1986: 32): "Maybe Asia [...] is [...] our main outcome!"), is now acting not only as a geo-economically 'semi-peripheral peripheral' state, but also as a country actively populated from outside. And it puts the Russian ethno-demographic transformation in direct dependence on the dynamics and direction of integration and disintegration processes in the Mega-Eurasia rapidly modifying its socio-economic 'landscape', characterised herewith by a clear dominance of the 'Muslim component' of the demographic growth of the potential. The number of Russians on the Russian Federation territory decreased in 2002-2010 by 4,873 thousand, or $4.2 \%$.

The gradual strengthening of the position of the Islamic Ummah (the ability to substantially increase their geo-ethno-cultural presence both in Western Europe and the central regions of Eurasia), the increasingly tangible global dominance of China, and the not-so-obvious yet but inevitable ascendancy of India, I believe, require our country to overcome the Eurocentrism traditional in it. In the recent years it has also been fed by globalisation, which in the long run will inevitably result in the weakening of the Western influence on Russian civilisation. It brings the possibility of developing a real multi-vector foreign policy. At the same time, the increasingly obvious dominance of the modern 'Eurasian space' constitutes a productive dialogue between Islam and Orthodoxy (this question is, as reasonably believed (Khakimov 2009), not yet solved in the framework of the Eurasian doctrine), a complementary co-evolution, and the historically developed symbiosis of the Turkic and Russian worlds (Martynov, Sazonova 2011, Druzhinin 2012a).

Of course, it is important to understand that both now and in the foreseeable future the position of Russia in Eurasia, the integration-disintegration processes typical of the Eurasian meta-region, and the ratio of the major centres of power are determined primarily by geo-economics, the struggle for a place in the global centre-periphery system. The economic progress and social opportunities of our country will, thus, to a large extent predetermine the dynamics of almost inevitable continuous depopulation of the Russian Federation prevailing in the previous years. In the years 1900-2010, within its modern territorial framework, the share of Russia in the world population declined from $4.5 \%$ to $2 \%$, and in 2050 this figure will not exceed $1.5 \%$. During the last inter-census period partial 'de-Russification' of the ethnic population structure was revealed to be typical of 72 units of the Russian Federation.

Since the mid-2000s the main source replenishing Russia's demographic losses has mainly been the Turkic (and predominantly Islamic) states of Central Asia. Per capita GDP in Russia exceeds that of Uzbekistan 4.8 times, of Kyrgyzstan, 7.2 times, and of Tajikistan, 7.9 times, which right now gives Russian depopulation features of a cultural (behavioural, value) transformation. Projected over the ethno-cultural situation, the observed ethno-demographic trend predetermines its future, predicted in particular almost half a century ago by Gasprinsky (1881: 36), who believed that "[...] in the future, perhaps near, Russia is destined to become one of the major Muslim states that [...] will by no means downgrade it as a great Christian power". The above not only updates the problem of inter-cultural and inter-denominational dialogue, but also significantly expands its social and geographical context, taking on features of a cross-border, cross-country and inter-civilisation one. There is an actual increase in Russia's poly-ethnicity, geographically manifested in the overlapping of 
mono-ethnic and multi-ethnic areas, growth and root-taking of other ethnic diasporas, the presence of extensive ethno-contact areas, and different-scale areas with intensive changes in the ethno-demographic structure. In this situation the key matter for our country with regard to its future is the adaptation and assimilation potential of Russian culture, its capacity for self-preservation (and, in part, for change) after it has perceived, filtered and processed extensive waves of cultural innovation brought from the West and the East, and from the adjacent countries of Eurasia. Equally essential is an adequate, clear perception of the identity of our country, shared by an overwhelming majority of Russian society (this question has still not been solved; National Idea 2012), including its civilisation, and hence the geographical aspect.

\section{Conclusions}

With an ever-increasing perception of both modern Russian and common Eurasian social and geographical space as a unity in diversity, it is important to understand that only a territorially unified, cost-effective, politically stable and socially prosperous Russia, open to cross-border cooperation (including other ethnic migrations), can provide a stable presence of Russian culture both in the post-Soviet space and in the world as a whole. A productive participation of Russia in the Eurasian space is connected in this regard with a non-admission of the extremely undesirable scenario, harmful to Russia, of its possible marginalisation, locking (including locking out from the Eurasian states and cultures) in a vague framework of the 'Russian world'. The hypothetically possible orientation to only one of the existing global 'power centres' seems to be equally disadvantageous. The specificity of the 'Eurasian space' requires our country to combine a consistent provision of a territorial, political, economic, and socio-cultural integrity of the Russian Federation (resisting the destructive idea, damaging for the Federation, of building a Russian 'national' mono-ethnic state) with a poly-vector policy and the prevention of both domestic and 'common-Eurasian' confrontational variances. An obvious priority and value, in this regard, is acquired by reintegration vectors in the
post-Soviet space, including those taking shape as the idea of a Eurasian Economic Union. Along with them we can observe, on the one hand, the actual re-objectification of Eurasia, and on the other, the internationalisation of Eurasian discourse, prolonged and intensified, taking place since the early 1990s, expanding its geographical and civilisation framework. Thus, the notion of Eurasia itself acquires a geo-cultural, geopolitical and geo-economic content; the need for social and geographical explication of this phenomenon is steadily increasing.

\section{References}

Andreev A.L., 2010. Evropa ili Evraziya? (Europe or Eurasia?). Vestnik Rossiyskoy akademii nauk 80(10): 913-917.

Bayford E., 2010. Evraziya, prishedshaya v dvizhenie (Eurasia which came into motion). Antropologicheskiy forum 13: 317-322.

Brzeziński Z., 1998. Velikaya shakhmatnaya doska. Gospodstvo Ameriki i ego geostrategicheskie imperativy (The grand chessboard. American primacy and its geostrategic imperatives). Mezhdunarodnye otnosheniya, Moscow.

Bykov A.N., 2006. Ekonomicheskaya integratsiya i ee perspektivy na postsovetskom evraziyskom prostranstve (Economic integration and its perspectives in the post-Soviet space). Rossiyskiy oneshneekonomicheskiy vestnik 7: 7-19.

Chelyshev E.P., 2010. Evraziya: problemy vostochno-zapadnogo sinteza $v$ russkoy kul'turnoy traditsii i nasledie evraziytsev (Eurasia: problems of the east-west synthesis in the Russian cultural tradition and the heritage of Eurasians). Prostranstvo $i$ Vremya 2: 8-16.

Dergachev V.A., 2011. Geopoliticheskaya teoriya bol'shikh mnogomernykh prostranstv. Monografiya (Geopolitical theory of large multi-dimensional spaces). (Elektronnoe izdanie na CD + Internet-giperssylki) - Izdatel'skiy proekt professora Dergacheva.

Dmitrevsky Yu.D., 1995. Edinoe evraziyskoe sotsial'no-ekonomicheskoe prostranstvo. Postanovka problemy, sovremennyy etap ee resheniya (Common Eurasian socio-economic space. The problem, current stage of its solution). Geografiya v shkole 4: 45-49.

Dostoevsky F.M., 1987. Poln. sobr. soch. (Complete works). Vol. 27.

Druzhinin A.G., 1996. Russkiy regionalizm: yavlenie v kontekste geoetnokul'turogeneza (Russian regionalism: phenomenon in the context of geo-ethno-cultural genesis). Nauchnaya mysl' Kavkaza 1: 3-10.

Druzhinin A.G., 2009. Global'noe pozitsionirovanie Yuga Rossii: faktory, osobennosti, strategii (Global positioning of the South of Russia: factors, special features, strategies). Izdvo YuFU, Rostov-na-Donu.

Druzhinin A.G., 2012a. Prostranstvennoe sotsial'no-ekonomicheskoe razvitie sovremennoy Rossii skvoz' prizmu nauchnykh idey L.N. Gumileva (Spatial social and economic development of modern Russia in the scientific thoughts of L.N. Gumilev). Vestnik Sankt-Peterburgskogo gosuniversiteta. Spetsial'nyy vypusk. K 100-letiyu L.N. Gumileva: 51-57. 
Druzhinin A.G. 2012b, Demografo-ekonomicheskaya dinamika regionov Yuga Rossii: dolgovremennye trendy i novye tendentsii $\mathrm{v}$ rossiyskom i global'nom kontekste (Demographic and economic dynamics of the Southern Russian regions: long-term trends and new tendencies in a Russian and a global context). Yuzhno-rossiyskiy forum: ekonomika, sotsiologiya, politologiya, sotsial'no-ekonomicheskaya geografiya $1(4)$ : 3-16.

Druzhinin A.G., 2013. Novaya kontseptualizatsiya Evrazii: vzglyad geografa-obshchestvoveda (New conceptualisation of Eurasia: a view of a social geographer). Sotsial'no-ekonomicheskaya geografiya. Vestnik Assotsiatsii rossiyskikh geografov-obshchestvovedov 2: 25-36.

Druzhinin A.G., 2014a. 'Prichernomorskaya sostavlyayushchaya' rossiysko-turetskogo vzaimodeystviya $\mathrm{v}$ sovremennom evraziyskom kontekste ('Black Sea constituent' of Russian-Turkish co-operation in the modern Eurasian context). Yuzhno-rossiyskiy forum: ekonomika, sotsiologiya, politologiya, sotsial'no-ekonomicheskaya geografiya 2 (9): 3-14.

Druzhinin A.G., 2014b. Polizavisimost' v tsentro-periferiynoy stratifikatsii territorial'noy organizatsii obshchestva: osnovy kontseptsii (Poly-dependence in the central-peripheral stratification of the territorial organisation of society: fundamentals and concepts). Sotsial'no-ekonomicheskaya geografiya. Vestnik Assotsiatsii rossiyskikh geografov-obshchestvovedov 3: 29-40.

Druzhinin A.G., Streletsky V.N., 2015. Kul'turnaya sostavlyayushchaya' obshchestvennoy geografii v sovremennoy Rossii: genezis, osobennosti i prioritetnye napravleniya issledovaniy ('Cultural branch' of human geography in contemporary Russia: genesis, main peculiarities, and priorities of development ) / / Izvestiya RAN. Ser. geograficheskaya 1: 5-20.

Dugin A.G., 1997. Osnovy geopolitiki (Fundamentals of geopolitics). Moscow.

Gasprinsky I., 1881. Russkoe musul'manstvo. Mysli, zametki i nablyudeniya (Russian Islamism. Thoughts, notes and observations). Simferopol.

Gerasimenko T.I., 2012. Vmeshchayushchiy landshaft i komplimentarnost' etnosov - osnova formirovaniya regional'noy identichnosti (Enclosing landscape and ethnos complementarily - a basis for regional identity formation). Vestnik Sankt-Peterburgskogo gosuniversiteta. Spetsial'nyy vypusk. K 100-letiyu L.N. Gumileva: 38-50.

Gladky Yu.N., 2006. Rossiya v labirintakh geograficheskoy sud'by (Russia in the labyrinths of the geographical destiny). St. Petersburg.

Godin Yu., 2009. Rossiya i SNG: geopoliticheskie vyvody (Russia and the CIS: conclusions of geo-politics). ME i MO 4: 90-94.

Inozemtsev V., 2012. Tranzitnoy strany iz Rossii uzhe ne vyydet (Russia won't become a transit country). Vedomosti 29 November 2012.

Kagansky V.L., 2007. Evraziyskaya mnimost (Eurasian ostensibility). In: Yakovenko I.G. (ed.), Rossiya kak tsivili- zatsiya: Ustoychivoe $i$ izmenchivoe. Nauchnyy sovet RAN 'Istoriya mirovoy kul'tury', Nauka: 531-590.

Khakimov R.S., 2009. Evraziya kak konfederatsiya stran i narodov Vostoka (Eurasia as a confederation of states and nations of the East). Uchenye zapiski Kazanskogo universiteta. Seriya: Gumanitarnye nauki 151(2-1): 248-254.

Kosov Yu.V., Toropygin A.V., 2011. Nekotorye osobennosti integratsionnykh protsessov na evraziyskom prostranstve (Some specific features of integration processes in the Eurasian space). Evraziyskaya integratsiya: ekonomika, pravo, politika 10: 157-163.

Lavrov S.B., 2000. Lev Gumilev. Sud'ba i idei (Lev Gumilev. Destiny and ideas). Svarog i K, Moscow.

Leskova I.V., 2012. Integratsionnyy potentsial evraziyskogo prostranstva (Integration potential of Eurasian space). Ekonomika i sotsium: sovremennye modeli razvitiya 3: 171175.

Martynov V.L., Sazonova E.I., 2011. Turtsiya mezhdu Zapadom i Vostokom (Turkey between the West and the East). Izvestiya RGO: 31-37.

Natsional'naya ideya Rossii (National idea of Russia), 2012. V 6 t. T. I. Nauchnyy ekspert, Moscow.

Novyy vzglyad na ekonomicheskuyu geografiyu. Doklad o mirovom razvitii (New insights into economic geography. Report on the global evolution). 2009. Moscow.

Postsovetskie gosudarstva (Post-Soviet states), 2004. Zh. Radvani (ed.). Armand Coline, Paris.

Putin V.V., 2011. Novyy integratsionnyy proekt dlya Evrazii: budushchee, kotoroe rozhdaetsya segodnya (New integration project for Eurasia: the future which is born today). Izvestiya 3 Oct. 2011.

Savitsky P., 1997. Kontinent Evraziya (Continent Eurasia). Agraf, Moscow.

Sinyak Yu.V., Beschinsky A.A., 2003. Vozmozhnaya rol' rossiyskogo prirodnogo gaza v sotsial'no-ekonomicheskom razvitiya evraziyskogo prostranstva v XXI veke (Possible role of Russian natural gas in the socio-economic development of Eurasian ). Problemy prognozirovaniya 5: 55-76.

Shuper V.A., 2003. Metodologiya geografii na perelome epoch (Methodology of geography at the turn of epochs). Izv. RAN. Ser. geograficheskaya 4: 27-35.

Treyvish A.I., 2012. Rossiya i drugie strany-giganty: vyzovy $X X I$ veka (Russia and other giant countries: challenges of the 21st century). Vyzovy XXI veka: priroda, obshchestvo, prostranstvo. Otvet geografov stran SNG, Moscow: 12-19.

Turovsky R., 1999. Politicheskaya geografiya (Political geography). Moscow.

Yaz'kova A., 2005. Yuzhnyy Kavkaz: uravnenie so mnogimi neizvestnymi (Southern Caucasus: equation with a number of unknowns). Vestnik Analitiki 2: 76-84.

Zamyatin D.N., 2009. Geokratiya: Evraziya kak obraz, simvol i proekt Rossiyskoy tsivilizatsii (Geocracy: Eurasia as an image, a symbol and a project of the Russian civilisation). In: Mitin I.I., Sost D.N., Zamyatin I.I. (eds), Rossiya: voobrazhenie prostranstva/prostranstvo voobrazheniya. Agraf, Moscow: 339-377. 